\title{
EKSTRAKSI DAN PENENTUAN AKTIVITAS ANTIOKSIDAN EKSTRAK UBI JALAR UNGU (Ipomoea batatas L.)
}

\author{
Agus SAFARI ${ }^{1}$, SANi DWININGRUM RAHAYU BR GinTING ${ }^{1}$, MUHAMMAd FAdHLILlah ${ }^{1}$, \\ SAADAH D. RACHMAN ${ }^{1}$, NENDEN I. ANGGRAENI ${ }^{1}$, DAN SAFRI ISHMAYANA ${ }^{1 *}$ \\ ${ }^{1}$ Departemen Kimia, Fakultas Matematika dan Ilmu Pengetahuan Alam, Universitas Padjadjaran \\ Jln. Raya Bandung-Sumedang km. 21 Jatinangor, Sumedang, Jawa Barat \\ *alamat email korespondensi: ishmayana@unpad.ac.id
}

\begin{tabular}{l} 
Informasi Artikel \\
\hline Riwayat Naskah : \\
Diterima pada 02 \\
Oktober 2019 \\
Diterima setelah \\
direvisi pada 20 \\
Desember 2019 \\
Diterbitkan pada 30 \\
Desember 2019
\end{tabular}

Kata Kunci: antioksidan; antosianin; eksraksi; ubi jalar ungu

Keywords: antioxidant; anthocyanin; extraction; purple sweet potato

\begin{abstract}
Abstrak/Abstract
Antosianin merupakan pigmen pewarna alami yang berwarna dan dapat berperan sebagai antioksidan. Senyawa ini dapat digunakan sebagai salah satu bahan tambahan makanan sebagai pewarna. Selain peranannya sebagai zat warna, antosianin juga dapat berperan sebagai senyawa antioksidan, sehingga ketika ditambahkan pada makanan akan menghasilkan suatu pangan fungsional. Salah satu bahan yang kaya akan antosianin adalah ubi jalar ungu (Ipomoea batatas L.). Tujuan dari penelitian ini adalah untuk mengekstraski antosianin dari ubi jalar ungu. Metode yang dilakukan meliputi preparasi antosianin melalui maserasi dengan etanol, pemekatan dengan teknik evaporasi vakum ekstrak ubi ungu, karakterisasi spektrum sinar tampak serta penentuan residu etanol pada ekstrak. Hasil yang diperoleh menunjukkan bahwa dari $500 \mathrm{~g}$ ubi jalar ungu segar yang diekstraksi dengan $1 \mathrm{~L}$ etanol diperoleh $8 \mathrm{~g}$ pasta ekstrak ubi jalar ungu. Karakterisasi dengan spektrofotometri pada pajang gelombang sinar tampak menghasilkan spektrum yang sama dengan spektrum yang telah dipublikasikan sebelumnya. Ekstrak yang diperoleh memiliki aktivitas antioksidan yang

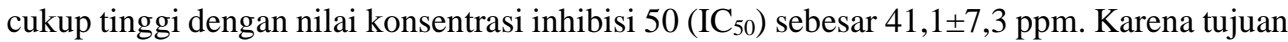
ekstraksi ini adalah untuk aplikasi pada bidang pangan, residu etanol yang terdapat pada ekstrak ditentukan dengan metode enzimatik menggunakan alkohol dehidrogenase dan diperoleh residu etanol sebanyak $0,122 \pm 0,033 \% \mathrm{v} / \mathrm{v}$.
\end{abstract}

\begin{abstract}
Anthocyanin is a natural colorant pigment and has good antioxidant activity. This compound can be used as food additive as colorant. Beside its role as natural colorant, when added to food, its antioxidant activity will make the food become a functional food. One of rich source of anthocyanin is purple sweet potato (Ipomoea batatas L.). The aim of the present study was to extract anthocyanin from purple sweet potato. The experiment was conducted by preparation of anthocyanin extract by maceration using ethanol, concentration of the extract using rotary vacuum evaporator, characterization of visible light spectrum and determination of residual ethanol in the extract. The results of the present study showed that from $500 \mathrm{~g}$ of fresh purple sweet potato macerated with $1 \mathrm{~L}$ of ethanol, $8 \mathrm{~g}$ of pasta extract was obtained. Characterization of the extract using spectrophotometer at visible light wavelength showed a match spectrum with previously published data. The extract has relatively high antioxidant value with $I C_{50}$ of $41.1 \pm 7.3$ ppm. Since this study was aimed to prepare extract for food additive, the ethanol residue in the extract was determined using alcohol dehydrogenase enzymatic assay and the result showed that the residual ethanol in the extract was only 0,122 $\pm 0,033 \% \mathrm{v} / \mathrm{v}$.
\end{abstract}

\section{PENDAHULUAN}

Pada saat ini banyak dikembangkan pangan fungsional, yaitu makanan yang tidak hanya berperan sebagai sumber energi, tetapi juga memiliki nilai tambah bagi kesehatan seperti makanan yang mengandung senyawa antioksidan [1]. Salah satu contoh senyawa yang memiliki aktivitas antioksidan adalah antosianin. Antosianin yang merupakan zat pewarna alami yang juga dapat berperan sebagai antioksidan yang bermanfaat bagi kesehatan tubuh. Salah satu peran antioksidan yaitu menangkap radikal bebas dalam tubuh sehingga memperlambat penuaan, mencegah kanker, dan penyakit degeneratif lainnya [1-5].

Antosianin merupakan suatu senyawa turunan flavonoid seperti yang ditunjukkan Gambar 1 yang terdiri atas antosianidin dan gugus gula yang terikat melalui ikatan glikosida pada posisi -3 [1, 2, 6, 7]. Kano et al. [2] telah menemukan delapan senyawa antosianin (senyawa A-H) yang terdapat dalam ekstrak ubi jalar ungu. Kedelapan senyawa tersebut memiliki perbedaan pada gugus sampingnya dan memiliki aktivitas antioksidan yang berbeda pula. Aktivitas antokisodan tertinggi ditunjukkan oleh senyawa $\mathrm{H}$, 
yang mengikat gugus metil, asam kafeat, dan asam ferulat masing-masing pada posisi R1, R2, dan R3. Spektrum antosianin yang diisolasi dari ubi jalar merah telah ditentukan oleh Cevallos-Casals \& Cisneros-Zevallos [8] dan hasilnya menunjukkan adanya pergeseran spektrum dari panjang gelombang maksimum dari rendah ke tinggi ketika $\mathrm{pH}$ antosianin diubah dari asam ke basa.

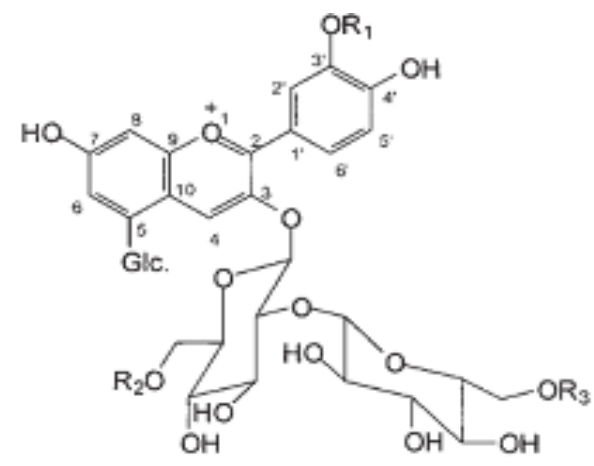

Gambar 1. Struktur umum senyawa antosianin yang diisolasi dari ubi jalar ungu. Gugus samping R1, R2, dan R3 berbeda-beda pada kedelapan senyawa yang telah berhasil diisolasi Kano et al. [2].

Antosianin terdapat dalam beberapa tanaman seperti ubi jalar ungu (Ipomoea batatas L.) sehingga cukup menarik untuk dikaji karena banyaknya manfaat dari kandungan antosianin tersebut [6, 9]. Dalam upaya mengembangkan pangan fungsional, pada penelitian sebelumnya yang dilakukan oleh Safari et al. [10] ubi jalar ungu yang dihidrolisis sebagian digunakan dalam pembuatan roti komposit. Roti tawar yang dihasilkan diharapkan menjadi pangan fungsional yang mengandung antioksidan dan volume pengembangan roti yang baik. Namun, roti komposit yang dihasilkan dari penelitian tersebut memiliki volume pengembangan yang kurang baik dibandingkan dengan roti yang terbuat dari tepung terigu saja. Selanjutnya pada penelitian yang dilakukan oleh Safari et al. [11], roti komposit tepung terigu dan pasta ubi jalar ungu telah dibuat dengan penambahan enzim $\alpha$-amilase pada adonan dapat meningkatkan volume pengembangan. Namun, aktivitas antioksidan pada roti komposit yang dihasilkan pada kedua penelitian tersebut belum ditentukan. Oleh karena itu pada penelitian ini dilaporkan ekstraksi antosianin dari ubi jalar ungu serta penentunan aktivitas antioksidannya.

\section{EKSPERIMEN}

\section{Material}

Bahan-bahan penelitian yang digunakan adalah ubi jalar ungu segar, air suling, etanol teknis $96 \% \mathrm{v} / \mathrm{v}$, asam klorida, natrium hidroksida, 2,2- diphenyl-1-picrylhydrazyl (DDPH), alkohol dehidrogenase, buffer semikarbazida, $\mathrm{NAD}^{+}$. Semua bahan kimia yang digunakan diperoleh dari Sigma Aldrich dengan grade p.a.

\section{Instrumentasi}

Alat yang digunakan pada penelitian ini yaitu blender, alat sentrifugasi, inkubator, rotary vacuum evaporator Büchi, spektrofotometer UVVis Genesys 10S, dan neraca analitik.

\section{Prosedur}

\section{Ekstraksi Ubi Jalar Ungu [9]}

Ubi jalar ungu yang digunakan diperoleh dari pasar Cileunyi, Bandung. Ubi jalar ungu dibersihkan dan dicuci lalu ditimbang sebanyak $500 \mathrm{~g}$ dan dipotong dadu kecil-kecil. Potongan ubi dihancurkan dengan blender dan dimasukkan ke dalam botol maserasi, kemudian ditambahkan dengan $1 \mathrm{~L}$ etanol teknis $96 \% \mathrm{v} / \mathrm{v}$ dan dimaserasi selama \pm 24 jam. Hasil maserasi disaring menggunakan kertas saring. Filtrat yang dihasilkan diuapkan dengan menggunakan rotary evaporator sehingga didapatkan ekstrak ubi jalar ungu. Jika tidak langsung digunakan, ekstrak disimpan dalam lemari es suhu $-4^{\circ} \mathrm{C}$.

\section{Penentuan Spektrum Sinar Tampak Ekstrak Ubi Jalar Ungu [8]}

Ekstrak ubi jalar ungu dilarutkan dengan air kemudian $\mathrm{pH}$ nya diatur dengan penambahan asam klorida $0.1 \mathrm{M}$ atau natrium hidroksida $0.1 \mathrm{M}$ sampai diperoleh pH 2,01; 6,44; dan 9,86. Larutan yang diperoleh kemudian ditentukan spektrumnya pada panjang gelombang $400-800 \mathrm{~nm}$.

\section{Penentuan Aktivitas Antioksidan Ekstrak Ubi Ungu serta Nilai $I_{50}$ [12]}

Penentuan uji aktivitas antioksidan ekstrak ubi ungu dilakukan dengan metode DPPH [12]. Sampel yang digunakan untuk pengujian aktivitas antioksidan adalah ekstrak yang diperoleh dari ubi jalar ungu. Tahapan awal adalah pembuatan sampel dengan konsentrasi 1000 ppm. Lalu dilakukan pengujian dengan variasi konsentrasi, yaitu 2,5; 5; 10; 25; dan 50 ppm. Sebanyak $4 \mathrm{~mL}$ sampel ditambah $1 \mathrm{~mL}$ DPPH 0,2 mM kemudian dikocok dengan vorteks. Campuran tersebut disimpan di ruangan gelap pada suhu ruang selama 30 menit. Selanjutnya dilakukan pengukuran absorban pada panjang gelombang $517 \mathrm{~nm}$. Perlakukan sama diulang untuk larutan blanko yang tidak berisi sampel (4 mL etanol dan $1 \mathrm{~mL}$ larutan $\mathrm{DPPH}$ ). 
Persen penghambatan dapat dihitung dengan menggunakan persamaan (1).

Daya hambat $(\%)=\frac{\mathrm{A}_{\text {blanko }}-\mathrm{A}_{\text {sampel }}}{\mathrm{A}_{\text {blanko }}} \times 100 \%$

Untuk menentukan nilai $\mathrm{IC}_{50}$, dibuat suatu grafik hubungan linear antara konsentrasi sampel dengan aktivitas antioksidan sebagai nilai daya hambat. Kemudian, konsentrasi ketika nilai daya hambat sebesar $50 \%$, yang merupakan nilai $\mathrm{IC}_{50}$, ditentukan dari persamaan garis linear yang diperoleh.

\section{Penentuan Residu Etanol pada Ekstrak Ubi Jalar} Ungu [13]

Kadar etanol ditentukan dengan metode enzimatik menggunakan enzim alkohol dehidrogenase [13]. Sebanyak $25 \mu \mathrm{L}$ sampel diambil dan ditambahkan dengan 1,25 mL buffer semikarbazida lalu diaduk. Kemudian ke dalamnya ditambahkan $25 \mu \mathrm{L}$ larutan reagen $\mathrm{NAD}^{+}$dan dikocok kembali. Terakhir ditambahkan sebanyak $5 \mu \mathrm{L}$ larutan alkohol dehidrogenase dan dikocok kembali. Campuran kemudian diinkubasi pada suhu $37^{\circ} \mathrm{C}$ selama 25 menit. Setelah diinkubasi, serapan ditentukan pada panjang gelombang 340 nm. Larutan standar etanol dibuat dengan konsentrasi 0,$01 ; 0,02 ; 0,04$; dan $0,05 \%$ (v/v). Konsentrasi sampel ditentukan dengan memplotkan serapan sampel pada grafik kurva baku.

\section{HASIL DAN PEMBAHASAN}

Ekstraksi merupakan salah satu metode pemisahan dua atau lebih komponen dengan menambahkan suatu pelarut yang tepat. Pada penelitian ini ekstraksi ubi ungu dilakukan dengan teknik maserasi. Pada teknik ini sampel ubi jalar ungu segar yang telah dihaluskan dengan cara diblender kemudian direndam dengan etanol teknis $96 \%$ v/v. Tahapan yang dilakukan yaitu ubi jalar ungu dicuci, dipotong dan dihaluskan dengan blender sambil ditambahkan pelarut. Perbandingan ubi jalar ungu dan pelarut yaitu 1:2 (sebanyak 500 $\mathrm{g}$ ubi ungu dimaserasi dalam $1 \mathrm{~L}$ etanol teknis). Maserasi dilakukan selama 24 jam di tempat tertutup dan wadah coklat. Selanjutnya dilakukan penyaringan dan pengeringan sampel dengan metode evaporasi vakum menggunakan rotary vacuum evaporator. Hasil ekstrak yang diperoleh dari evaporator berupa pasta ubi ungu sebanyak $8 \mathrm{~g}$ dari $800 \mathrm{~mL}$ ekstrak cair yang diperoleh. Ekstraksi ubi ungu dilakukan untuk mengekstrak antosianin

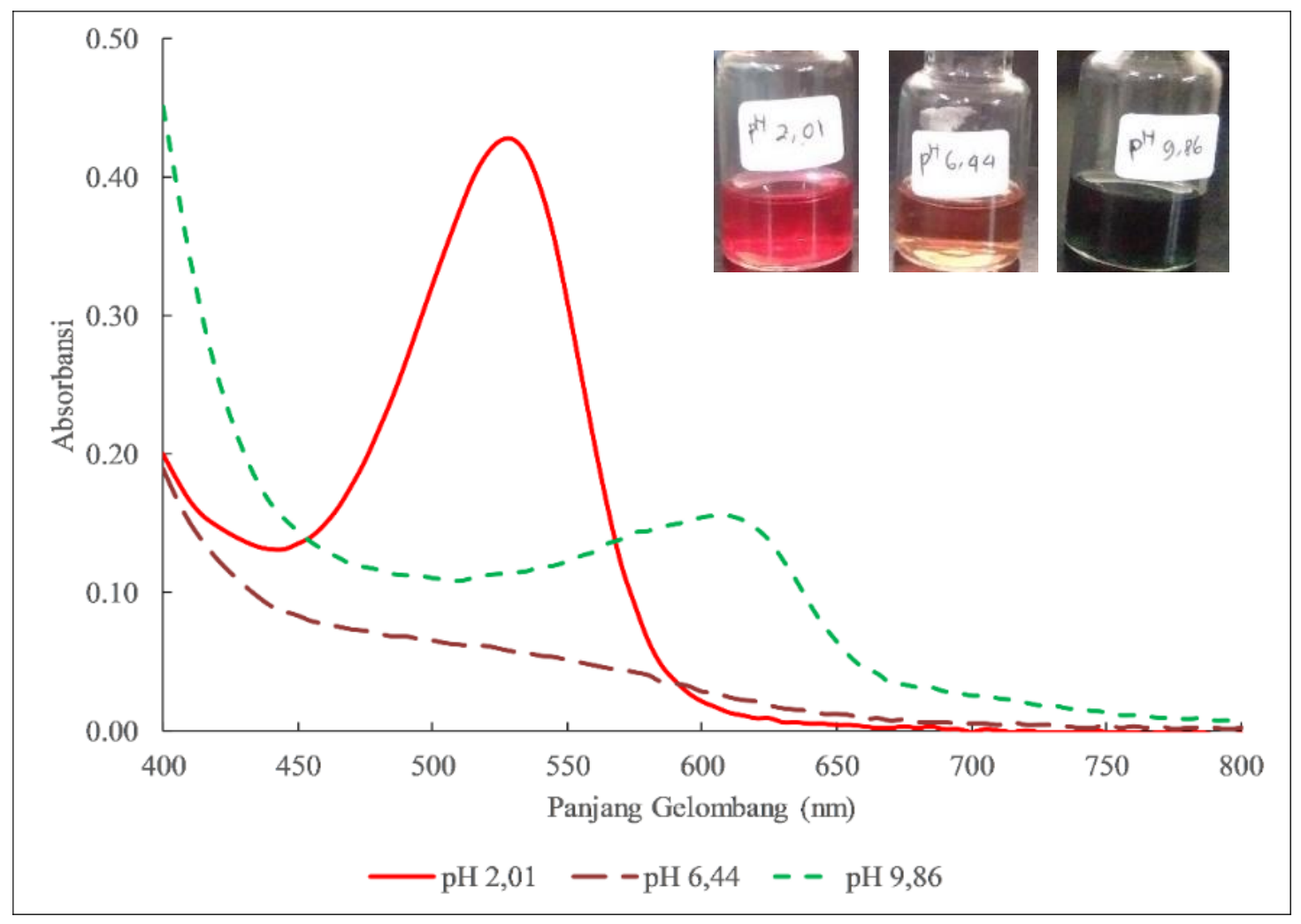

Gambar 2. Spektrum sinar tampak ekstrak ubi jalar ungu yang diekstraksi dengan metode maserasi menggunakan etanol teknis $96 \%$ v/v. Gambar di pojok kanan atas adalah penampakan larutan ekstrak pada berbagai pH sesuai yang tercantum pada gambar. 
yang merupakan pigmen warna ungu yang terdapat pada ubi jalar ungu.

Ekstrak ubi jalar ungu dikarakterisasi dengan menentukan spektrum pada panjang gelombang sinar tampak. Pengukuran spektrum dilakukan pada panjang gelombang 400-600 nm setelah sampel diatur pH-nya menjadi 2,01; 6,44; dan 9,28. Hasil pengukuran spektrum antosianin ekstrak ubi ungu ditunjukkan pada Gambar 2. Hasil penelitian ini menunjukkan bahwa panjang gelombang maksimum ekstrak bergeser dari panjang gelombang rendah ke panjang gelombang yang lebih tinggi ketika $\mathrm{pH}$ diubah dari $\mathrm{pH}$ yang rendah ke $\mathrm{pH}$ yang lebih tinggi. Seperti dapat dilihat pada Gambar 2, pada $\mathrm{pH}$ 2,01 panjang gelombang maksimum terdeteksi pada $530 \mathrm{~nm}$, sedangkan pada $\mathrm{pH}$ 6,44 spektrum relatif datar, sedangkan pada $\mathrm{pH}$ 9,86 panjang gelombang maksimum terdeteksi pada $610 \mathrm{~nm}$. Hasil pengukuran serupa untuk antosianin yang diisolasi dari ubi jalar merah juga dilaporkan oleh Cevallos-Casals \& CisnerosZevallos [8] yang mengamati adanya pergeseran spektrum dari panjang gelombang rendah ke tinggi ketika $\mathrm{pH}$ larutan diubah dari asam menuju basa.

Aktivitas antioksidan ekstrak ubi ungu hasil evaporasi ditentukan aktivitas antioksidannya menggunakan metode DPPH. Pengukuran larutan DPPH dilakukan pada panjang gelombang $517 \mathrm{~nm}$. Larutan DPPH warna ungu akan mengalami reduksi ketika bereaksi dengan senyawa yang mengandung pendonor elektron sehingga warna ungu akan memudar.
$\mathrm{IC}_{50}$ adalah konsentrasi efektif dari ekstrak ubi ungu yang mampu menangkal 50\% dari total DPPH dalam larutan. Nilai IC $_{50}$ ekstrak ubi jalar ungu dan asam askorbat yang ditentukan pada penelitian ini ditunjukkan pada Tabel 1. Hasil peneltian ini menunjukkan bahwa ekstrak ubi jalar ungu memiliki nilai $\mathrm{IC}_{50}$ sebesar 41,1 \pm 7,3 ppm. Sebagai pembanding, dilakukan pengukuran aktivitas antioksidan asam askorbat, dan diperoleh nilai $\mathrm{IC}_{50}$ sebesar $1,92 \pm 0,08 \mathrm{ppm}$. Nilai $\mathrm{IC}_{50}$ ekstrak ubi ungu dan asam askorbat tergolong nilai yang sangat kuat untuk menangkal radikal bebas menurut penggolongan yang dijelaskan oleh Tristantini et al. [14].

Tabel 1. Nilai hasil uji $\mathrm{IC}_{50}$ ekstrak ubi jalar ungu dan asam askorbat dengan menggunakan metode DPPH. Ekstrak ubu jalar ungu diuji empat kali sedangkan asam askorbat diuji 2 kali. Nilai rata-rata diikuti oleh nilai simpangan baku.

\begin{tabular}{ccc}
\hline Sampel & $\begin{array}{c}\text { IC50 } \\
(\mathbf{p p m})\end{array}$ & $\begin{array}{c}\text { Rata-rata IC50 } \\
(\mathbf{p p m})\end{array}$ \\
\hline \multirow{3}{*}{ Ekstrak ubi jalar } & 35,1 & \\
ungu & 34,5 & $41,1 \pm 7,3$ \\
& 47,3 & \\
& 47,5 & \\
\hline \multirow{2}{*}{ Asam askorbat } & 1,86 & \multirow{2}{*}{$1,92 \pm 0,08$} \\
\hline
\end{tabular}

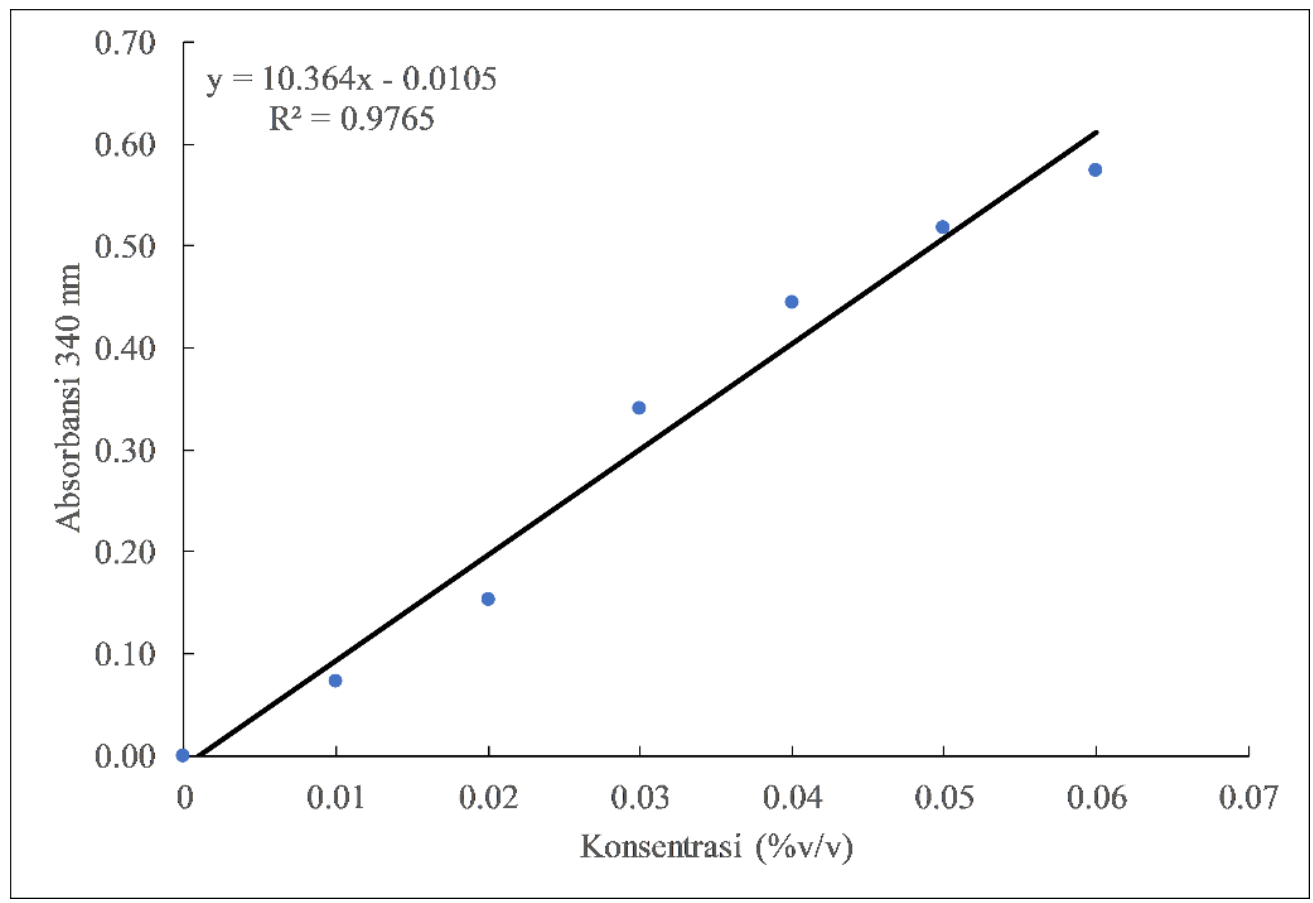

Gambar 3. Kurva baku etanol pada berbagai konsentrasi. Kadar etanol ditentukan dengan metode enzimatik menggunakan enzim alkohol dehydrogenase dan hasil reaksinya diukur pada panjang gelombang $340 \mathrm{~nm}$. 
al-Kimiya, Vol. 6, No. 2 (46-51) Desember 2019/Jumadil Ula 1441 H

Tabel 2. Hasil penentuan kadar etanol ekstrak ubi jalar ungu

\begin{tabular}{ccccc}
\hline Sampel & $\begin{array}{c}\text { Absorbansi } \\
\mathbf{3 4 0} \mathbf{~ n m}\end{array}$ & $\begin{array}{c}\text { Faktor } \\
\text { pengeceran } \\
(\mathbf{k a l i})\end{array}$ & $\begin{array}{c}\text { Konsentrasi } \\
\text { etanol } \\
(\boldsymbol{\%} \mathbf{~ v / v )}\end{array}$ & $\begin{array}{c}\text { Rata-rata } \\
\text { Konsentrasi etanol } \\
(\mathbf{\%} \text { v/v })\end{array}$ \\
\hline Ekstrak ubi jalar ungu & 0,092 & 10 & 0,099 & $0,122 \pm 0,033$ \\
\hline
\end{tabular}

Karena tujuan dari penelitian ini adalah aplikasi ekstrak ubi jalar ungu untuk bahan tambahan pangan, maka kadar etanol yang terdapat dalam ekstrak ubi ungu hasil evaporasi ditentukan dengan metode enzimatik menggunakan enzim alkohol dehidrogenase. Untuk mengetahui kadar etanol sisa pada ekstrak hasil evaporasi, sebanyak 1 gram ekstrak ubi jalar ungu dilarutkan dalam 10 $\mathrm{mL}$ air suling dan kadar etanol ditentukan dengan mencampurkan reagen seperti tercantum pada metode. Kurva baku yang digunakan dan hasil pengukuran kadar etanol ditunjukkan pada Gambar 3 dan Tabel 2. Hasil penelitian ini menunjukkan bahwa ekstrak ubi jalar ungu masih memiliki kandungan etanol sebesar 0,122 \pm $0,033 \%$ v/v. Konsentrasi ini sangat rendah dan jika dicampurkan sebagai bahan tambahan makanan, konsentrasinya akan menjadi jauh lebih kecil. Menurut fatwa MUI No. 10 tahun 2018, kadar etanol yang diperkenankan dalam produk akhir makanan adalah $0,5 \%$ selama etanol yang digunakan bukan berasal dari proses produksi khamr [15]. Sehingga dari segi keamanan pangan, ekstrak yang diperoleh dapat diaplikasikan sebagai bahan tambahan pangan.

\section{SIMPULAN}

Randemen ekstrak ubi jalar ungu yang diperoleh melalui proses maserasi pada penelitian ini adalah sebesar 1,6\% (8 g dari $500 \mathrm{~g}$ ubi jalar ungu segar). Karakterisasi ekstrak menunjukkan spektrum sinar tampak yang sama dengan spektrum antosianin yang telah dipublikasikan sebelumnya, sehingga memperkuat dugaan bahwa ekstrak yang diperoleh adalah senyawa antosianin. Ekstrak yang diperoleh memiliki aktivitas antioksidan yang kuat dengan nilai IC $_{50}$ sebesar 41,1 $\pm 7,3 \mathrm{ppm}$. Residu etanol yang terdapat dalam ekstrak sebesar $0,122 \pm 0,033 \% \mathrm{v} / \mathrm{v}$, sehingga dapat diaplikasikan sebagai bahan tambahan pangan.

\section{REFERENSI}

[1] A. Li, R. Xiao, S. He, X. An, Y. He, C. Wang, et al., "Research Advances of Purple Sweet Potato Anthocyanins: Extraction, Identification, Stability, Bioactivity, Application, and Biotransformation", Molecules, vol. 24, no. 21, pp. 3816, 2019.
[2] M. Kano, T. Takayanagi, K. Harada, K. Makino, and F. Ishikawa, "Antioxidative activity of anthocyanins from purple sweet potato, Ipomoera batatas cultivar Ayamurasaki", Bioscience, Biotechnology, and Biochemistry, vol. 69, no. 5, pp. 979-988, 2005.

[3] I. W. P. Sutirta-Yasa, I. M. Jawi, I. B. Ngurah, and A. A. N. Subawa, "Umbi ubi jalar ungu Bali (Ipomoea batatas) di transaminase serum, malondialdehide hepar dan alkohol kronis", Indonesian Journal of Clinical Pathology and Medical Laboratory, vol. 17, no. 3, pp. 151-154, 2011.

[4] S. Lim, J. Xu, J. Kim, T. Y. Chen, X. Su, J. Standard, et al., "Role of anthocyaninenriched purple-fleshed sweet potato p40 in colorectal cancer prevention", Molecular Nutrition \& Food Research, vol. 57, no. 11, pp. 1908-1917, 2013.

[5] I. Suda, T. Oki, M. Masuda, M. Kobayashi, Y. Nishiba, and S. Furuta, "Physiological functionality of purple-fleshed sweet potatoes containing anthocyanins and their utilization in foods", Japan Agricultural Research Quarterly: JARQ, vol. 37, no. 3, pp. 167-173, 2003.

[6] J. Martín, M. J. Navas, A. M. JiménezMoreno, and A. G. Asuero, "Anthocyanin pigments: Importance, sample preparation and extraction", in Phenolic compoundsNatural sources, importance and applications, M. Soto-Hernández, M. PalmaTenango, and R. García-Mateos, Eds., ed London: IntechOpen, pp. 117-152, 2017.

[7] T. Pervaiz, J. Songtao, F. Faghihi, M. S. Haider, and J. Fang, "Naturally occurring anthocyanin, structure, functions and biosynthetic pathway in fruit plants", Journal of Plant Biochemistry and Physiology, vol. 5, no. 2, pp. 1000187, 2017.

[8] B. A. Cevallos-Casals and L. CisnerosZevallos, "Stability of anthocyanin-based aqueous extracts of Andean purple corn and red-fleshed sweet potato compared to synthetic and natural colorants", Food Chemistry, vol. 86, no. 1, pp. 69-77, 2004.

[9] N. El Husna, M. Novita, and S. Rohaya, "Kandungan antosianin dan aktivitas 
antioksidan ubi jalar ungu segar dan produk olahannya", Agritech, vol. 33, no. 3, pp. 296302, 2013.

[10] A. Safari, D. S. Kamara, F. Silalahi, M. Fadhlillah, I. Kardi, and S. Ishmayana, "Partial hydrolysis of purple sweet potato flour by amylase from Saccharomycopsis fibuligera and its application for composite breadmaking", The Journal of Microbiology, Biotechnology and Food Sciences, vol. 2, no. 5, pp. 2340-2343, 2013.

[11] A. Safari, S. Ishmayana, S. Q. Aini, S. D. Rachman, M. Yusuf, M. Fadhlillah, et al., "Penggunaan enzim $\alpha$-amilase dari Saccharomycopsis fibuligera R64 untuk peningkatan kualitas roti komposit terigu-ubi jalar ungu", Al-Kimia, vol. 5, no. 2, pp. 193207, 2017.
[12] H. Hayastika, A. Ansharullah, and N. Asyik, "Pengaruh substitusi tepung kedelai (Glycine max L.) terhadap aktivitas antioksidan roti tawar", Jurnal Sains dan Teknologi Pangan, vol. 2, no. 4, pp. 684-691, 2017.

[13] S. Ishmayana, M. Fadhlillah, Y. Kristia, and H. Budiman, "Validation of a modified alcohol dehydrogenase assay for ethanol determination", Current Chemistry Letters, vol. 4, no. 2, pp. 77-84, 2015.

[14] D. Tristantini, A. Ismawati, B. T. Pradana, and J. G. Jonathan, "Pengujian aktivitas antioksidan menggunakan metode DPPH pada daun tanjung (Mimusops elengi L)", in Seminar Nasional Teknik Kimia Kejuangan, Yogyakarta, 2016, pp. G1-1 - G1-6.

[15] H. Heryani. (2019, October $3^{\text {rd }}$ ). Memahami fatwa MUI tentang kadar etanol pada produk makanan dan minuman. Available: http://www.halalmui.org/mui14/index.php/m ain/detil_page/48/27571. 